\title{
Chemical Constituents and Anticancer Effects of the Essential Oil from Leaves of Xylopia laevigata
}

Authors

Affiliations
Jullyana de S. S. Quintans ${ }^{1}$, Bruno M. Soares ${ }^{2}$, Rosana P. C. Ferraz ${ }^{1}$, Allan C. A. Oliveira ${ }^{1}$, Thanany B. da Silva ${ }^{3}$, Leociley R. A. Menezes ${ }^{3}$, Marília F. C. Sampaio ${ }^{3}$, Ana Paula do N. Prata ${ }^{4}$, Manoel O. Moraes ${ }^{2}$, Claudia Pessoa ${ }^{2}$, Angelo R. Antoniolli ${ }^{1}$, Emmanoel V. Costa ${ }^{3}$, Daniel P. Bezerra ${ }^{1}$

The affiliations are listed at the end of the article
Key words

- Xylopia laevigata

- Annonaceae

- essential oil

- chemical composition

- antitumor received August 30, 2012 revised October 15, 2012 accepted Dec. 2, 2012

\section{Bibliography}

Dol http://dx.doi.org/

10.1055/s-0032-1328091

Published online January 10 ,

2013

Planta Med 2013; 79: 123-130

(c) Georg Thieme Verlag KG

Stuttgart · New York .

ISSN 0032-0943

\section{Correspondence}

Prof. Dr. Daniel P. Bezerra Department of Physiology Federal University of Sergipe Av. Marechal Rondon, Jardim Rosa Elze

49100-000, São Cristóvão

Sergipe

Brazil

Phone: + 557921056644 danielpbezerra@gmail.com

\section{Abstract}

$\nabla$

Xylopia laevigata, popularly known as "meiú" and "pindaíba", is a medicinal plant used in the folk medicine of the Brazilian Northeast for several purposes. The chemical constituents of the essential oil from leaves of $X$. laevigata, collected from wild plants growing at three different sites of the remaining Atlantic forest in Sergipe State (Brazilian Northeast), were analyzed by GC/FID and GC/ MS. The effect of the essential oil samples was assessed on tumor cells in culture, as well on tumor growth in vivo. All samples of the essential oil were dominated by sesquiterpene constituents. A total of 44 compounds were identified and quantified. Although some small differences were observed in the chemical composition, the presence of $\gamma$-muurolene $(0.60-17.99 \%), \delta$-cadinene (1.15-13.45\%), germacrene B (3.22-7.31\%), $\alpha$-copaene (3.33-5.98\%), germacrene D (9.09-
$60.44 \%)$, bicyclogermacrene (7.00-14.63\%), and (E)-caryophyllene (5.43-7.98\%) were verified as major constituents in all samples of the essential oil. In the in vitro cytotoxic study, the essential oil displayed cytotoxicity to all tumor cell lines tested, with the different samples displaying a similar profile; however, they were not hemolytic or genotoxic. In the in vivo antitumor study, tumor growth inhibition rates were $37.3-42.5 \%$. The treatment with the essential oil did not significantly affect body weight, macroscopy of the organs, or blood leukocyte counts. In conclusion, the essential oil from the leaves of $X$. laevigata is chemically characterized by the presence of $\gamma$ muurolene, $\delta$-cadinene, germacrene B, $\alpha$-copaene, germacrene $\mathrm{D}$, bicyclogermacrene, and (E)-caryophyllene as major constituents and possesses significant in vitro and in vivo anticancer potential.

\section{Introduction}

\section{$\nabla$}

The Xylopia species (family Annonaceae) are aromatic plants that have both nutritional and medicinal uses. Several studies have reported cytotoxic activity for plants belonging to this genus, such as Xylopia aethiopica (Dunal) A. Rich. [1], Xylopia aromatica (Lam.) Mart. in Mart. [2], Xylopia langsdorffiana St.-Hil. \& Tul. [3], and Xylopia sericea A.St.-Hil. [4].

Xylopia laevigata (Mart.) R.E. Fries is a medicinal plant found in the tropical American forest. In Brazil, it is popularly known as "meiú" and "pindaíba" and can be found in the States of Piauí, Paraiba, Sergipe, Rio de Janeiro, and São Paulo [5]. Although the principles of the popular use of this plant are almost unknown, by interview of the local population, we found that a decoction of its leaves and flowers is used in the folk medicine of the Brazilian Northeast for several purposes, in- cluding painful disorders, heart disease, and inflammatory conditions. In addition, some Xylopia species have been used in the folk medicine for treating tumors. Nonetheless, almost no scientific research was made of this plant.

A phytochemical and biological study of the stem from X. laevigata was performed by Silva et al. [6]. The ent-kaurane diterpenoids, ent-kaur-16-en19-oic acid, 4-epi-kaurenic acid, ent-16 $\beta$-hydroxy-17-acetoxy-kauran-19-al, ent-3 $\beta$-hydroxykaur-16-en-19-oic acid, and ent-16 $\beta, 17$-dihydroxy-kauran-19-oic acid, as well as spathulenol and a mixture of $\beta$-sitosterol, stigmasterol, and campesterol, were isolated from the hexane extract from X. laevigata stem. Potent larvicidal activity against Aedes aegypti larvae and antifungal activity against Candida glabrata and Candida dubliniensis were found for ent-3 $\beta$-hydroxykaur-16-en-19-oic acid. However, chemical analysis or investigation of the biological properties 
of the essential oil from leaves of $X$. laevigata has not been previously performed.

The chemical composition of the essential oil from leaves of $X$. laevigata, collected from wild plants growing at three different sites of the remaining Atlantic forest in Sergipe State (Brazilian Northeast), was analyzed by GC/FID and GC/MS. In addition, the effect of the essential oil samples was assessed on tumor cells in culture as well as on tumor growth in vivo.

\section{Material and Methods}

$\nabla$

Reagents

5-Fluorouracil (5-FU, purity $>99 \%$ ), doxorubicin (purity $>98 \%$ ), 3-(4,5-dimethyl-2-thiazolyl)-2,5-diphenyl-2H-tetrazolium bromide (MTT), ficoll-hypaque, phytohemagglutinin, and resazurin were purchased from Sigma Chemical Co. Triton X-100 (purity $>98 \%$ ) was purchased from Vetec. RPMI 1640 medium, fetal bovine serum, penicillin, and streptomycin were purchased from Cultilab. Carbon dioxide $\left(\mathrm{CO}_{2}\right)$ was purchased from White Martins. All other reagents were of analytical grade.

\section{Cells}

The cytotoxicity of the essential oil was tested against HL-60 (promyelocytic leukemia), OVACAR-8 (ovarian carcinoma), SF295 (glioblastoma), and HCT-116 (colon carcinoma) human cancer cell lines, all obtained from the National Cancer Institute, Bethesda, MD, USA. Cells were grown in RPMI-1640 medium supplemented with $10 \%$ fetal bovine serum, $2 \mathrm{mM}$ glutamine, $100 \mu \mathrm{g} / \mathrm{mL}$ streptomycin, and $100 \mathrm{U} / \mathrm{mL}$ penicillin, and incubated at $37^{\circ} \mathrm{C}$ with a $5 \% \mathrm{CO}_{2}$ atmosphere.

Sarcoma 180 tumor cells, which had been maintained in the peritoneal cavity of Swiss mice, were obtained from the Laboratory of Experimental Oncology at the Federal University of Ceará.

In order to get healthy human peripheral blood mononuclear cells (PBMC), heparinized blood (from healthy, nonsmoking donors who had not taken any drug at least 15 days prior to sampling) was collected, and the PBMC were isolated by a standard method of density-gradient centrifugation over ficoll-hypaque. The PBMC were washed and resuspended. Cells were grown under the same conditions as above plus the addition of phytohemagglutinin (4\%). The Human Research Ethics Committee approved this experimental protocol.

\section{Animals}

A total of 40 Swiss mice (males, 25-30 g), obtained from the central animal house of the Federal University of Sergipe, Brazil, were used. Animals were housed in cages with free access to food and water. All animals were kept under a 12:12-h light-dark cycle (lights on at 6:00 a.m.). Animals were treated according to the ethical principles for animal experimentation of SBCAL (the Brazilian association of laboratory animal science), Brazil. The Animal Studies Committee from the Federal University of Sergipe approved the experimental protocol (number 08/2012).

\section{Plant material}

$X$. laevigata leaves were collected from wild plants growing at three different sites of the remaining Atlantic forest in Sergipe State (Brazilian Northeast). Sample A (voucher number 15440) was collected in April 2010 at Itabaiana Mountain National Park in the Municipality of Itabaiana (coordinates: S $10^{\circ} 44^{\prime} 53^{\prime \prime}$ W $37^{\circ}$ $20^{\prime} 21^{\prime \prime}$ ). Sample B (voucher number 15443) was collected in
March 2010 at "Mata do Crasto" in the Municipality of Santa Luzia do Itanhy (coordinates: S $11^{\circ} 22^{\prime} 54^{\prime \prime} \mathrm{W} 37^{\circ} 25^{\prime} 15^{\prime \prime}$ ). And sample C (voucher number 17359) was collected in July 2010 near the campus of the Federal University of Sergipe in the Municipality of São Cristóvão (coordinates: S $10^{\circ} 55^{\prime} 08^{\prime \prime}$ W $\left.37^{\circ} 06^{\prime} 13^{\prime \prime}\right)$. All specimens were obtained from flowering plants. The species was identified by Dr. Ana Paula do Nascimento Prata, a plant taxonomist from the Department of Biology at the Federal University of Sergipe. The voucher botanic specimens were deposited at the Herbarium of the Federal University of Sergipe.

\section{Essential oil isolation and chemical analysis}

Oil isolation: The $X$. laevigata leaf specimen samples ( $200 \mathrm{~g}$ each) were dried separately in a stove with circulating air at $40^{\circ} \mathrm{C}$ for $24 \mathrm{~h}$ and submitted to hydrodistillation for $3 \mathrm{~h}$ using a Clevenger-type apparatus (Amitel). The hydrodistillation was performed in triplicate. The essential oil was dried over anhydrous sodium sulphate and stored in a freezer until analysis. The essential oil yields $(\mathrm{v} / \mathrm{w})$, calculated from dry plant weight, were $1.18 \pm 0.13 \%$ for sample A, $1.58 \pm 0.12 \%$ for sample B, and $1.40 \pm 0.14 \%$ for sample $C$.

GC/FID analysis: GC analyses were carried out using a Shimadzu GC-17A fitted with a flame ionization detector (FID) and an electronic integrator. Separation of the compounds was achieved employing a ZB-5MS fused capillary column $(30 \mathrm{~m} \times 0.25 \mathrm{~mm}$ $\times 0.25 \mu \mathrm{m}$ film thickness) coated with $5 \%$-phenyl-arylene- $95 \%$ methylpolysiloxane. Helium was the carrier gas at $1.2 \mathrm{~mL} / \mathrm{min}$ flow rate. The column temperature program was: $50^{\circ} \mathrm{C} / 2 \mathrm{~min}$, then a temperature increase of $4^{\circ} \mathrm{C} / \mathrm{min}$ to $200^{\circ} \mathrm{C}$, followed by another temperature increase of $15^{\circ} \mathrm{C} / \mathrm{min}$ to $300^{\circ} \mathrm{C}$, finishing with $300^{\circ} \mathrm{C} / 15 \mathrm{~min}$. The injector and detector temperatures were $250^{\circ} \mathrm{C}$ and $280^{\circ} \mathrm{C}$, respectively [7]. Samples $\left(0.5 \mu \mathrm{L}\right.$ in $\left.\mathrm{CH}_{2} \mathrm{Cl}_{2}\right)$ were injected with a $1: 100$ split ratio. Retention indices were generated with a standard solution of $n$-alkanes $\left(C_{9}-C_{18}\right)$. Peak areas and retention times were measured by an electronic integrator. The relative amounts of individual compounds were computed from GC peak areas without FID response factor correction. GC/MS analysis: GC/MS analyses were performed on a Shimadzu QP5050A GC/MS system equipped with an AOC-20i auto-injector. A J\&W Scientific DB-5MS (coated with 5\%-phenyl-95\%-methylpolysiloxane) fused capillary column $(30 \mathrm{~m} \times 0.25 \mathrm{~mm} \times 0.25 \mu \mathrm{m}$ film thickness) was used as the stationary phase. MS were taken at $70 \mathrm{eV}$ with a scan interval of $0.5 \mathrm{~s}$ and fragments from $40-$ $500 \mathrm{Da}$. All other conditions were similar to the GC analysis [7].

\section{Identification of constituents}

The essential oil components were identified by comparing the retention times of the GC peaks with standard compounds ran under identical conditions, by comparison of retention indices [8] and MS [9] with those in the literature, and by comparison of MS with those stored in the NIST and Wiley databases.

\section{In vitro cytotoxic evaluation of the essential oil}

Determination of the effect of the essential oil on cultured tumor and normal cells: Tumor cell growth was quantified by the ability of living cells to reduce the yellow dye MTT to a purple formazan product, as described by Mossman [10]. For all experiments, $100 \mu \mathrm{L}$ of a solution of cells $\left(0.7 \times 10^{5}\right.$ cells/mL for adherent cells or $0.3 \times 10^{6}$ cells $/ \mathrm{mL}$ ) were seeded in 96 -well plates. After $24 \mathrm{~h}$, the essential oil $(0.39-50 \mu \mathrm{g} / \mathrm{mL})$, dissolved in dimethyl sulfoxide (DMSO), was added to each well (using the HTS - highthroughput screening - Biomek 3000; Beckman Coulter, Inc.) and incubated 
for $72 \mathrm{~h}$. For this, a stock solution ( $10 \mathrm{mg} / \mathrm{mL})$ was prepared using DMSO, and then this stock solution was diluted using medium. Doxorubicin was used as the positive control. Negative control was treated with the vehicle used for diluting the test substance (0.5\% DMSO). At the end of incubation, the plates were centrifuged, and the medium was replaced by fresh medium $(150 \mu \mathrm{L})$ containing $0.5 \mathrm{mg} / \mathrm{mL}$ MTT. Three hours later, the formazan product was dissolved in $150 \mu \mathrm{L}$ of DMSO, and the absorbance was measured using a multiplate reader (DTX 880 Multimode Detector; Beckman Coulter, Inc.). The drug effect was quantified as the percentage of control absorbance of reduced dye at $595 \mathrm{~nm}$.

PBMC cell growth was determined by the Alamar blue assay, as described by Ahmed et al. [11]. For all experiments, $100 \mu \mathrm{L}$ of a solution of cells $\left(0.3 \times 10^{6}\right.$ cells $\left./ \mathrm{mL}\right)$ were seeded in 96 -well plates. After $24 \mathrm{~h}$, the essential oil $(0.39-50 \mu \mathrm{g} / \mathrm{mL})$, dissolved in DMSO, was added to each well (using HTS, high-throughput screening, Biomek 3000, Beckman Coulter, Inc.) and incubated for $72 \mathrm{~h}$. Doxorubicin was used as the positive control. Negative control was treated with the vehicle used for diluting the test substance (0.5\% DMSO). Twenty-four hours before the end of incubation, $10 \mu \mathrm{L}$ of stock solution $(0.312 \mathrm{mg} / \mathrm{mL}$ ) of Alamar blue (Resazurin) was added to each well. The absorbance was measured using a multiplate reader (DTX 880 Multimode Detector; Beckman Coulter ${ }^{\circledR}$ ), and the drug effect was quantified as the percentage of control absorbance at $570 \mathrm{~nm}$ and $595 \mathrm{~nm}$.

Determination of the effect of the essential oil on mouse erythrocytes: The hemolytic activity was performed using mouse erythrocyte, as described by Jimenez et al. [12]. The test was performed in 96 -well plates using a $2 \%$ mouse erythrocyte suspension in $0.85 \% \mathrm{NaCl}$ containing $10 \mathrm{mM} \mathrm{CaCl}_{2}$. The essential oil samples were tested at concentrations ranging from 31.25 to $500 \mu \mathrm{g} /$ $\mathrm{mL}$. After incubation at room temperature for $30 \mathrm{~min}$ and centrifugation, the supernatant was removed, and the hemoglobin released was measured spectrophotometrically as the absorbance at $540 \mathrm{~nm}$.

Determination of the genotoxic effect of the essential oil by the alkaline comet assay: The alkaline $(\mathrm{pH}>13)$ version of the comet assay (Single Cell Gel Electrophoresis) was performed as described by Singh et al. [13] with minor modifications [14]. Slides were prepared in duplicate, and 100 cells were screened per sample (50 cells from each duplicate slide) using a fluorescence microscope (Zeiss) equipped with a 515-560 nm excitation filter, a $590 \mathrm{~nm}$ barrier filter, and a 40X objective. Cells were scored visually into five classes according to tail length: (1) class 0: undamaged, without a tail; (2) class 1: with a tail shorter than the diameter of the head (nucleus); (3) class 2: with a tail length $1-2 \times$ the diameter of the head; (4) class 3: with a tail longer than $2 \times$ the diameter of the head; (5) class 4: comets with no heads. A value of damage index (DI) was assigned to each comet according to its class, using the formula: $\mathrm{DI}=(0 \times \mathrm{n} 0)+(1 \times \mathrm{n} 1)+(2 \times \mathrm{n} 2)+(3 \times$ $n 3)+(4 \times n 4)$, where $n=$ number of cells in each class analyzed. The damage index ranged from 0 (completely undamaged: 100 cells $\times 0$ ) to 400 (with maximum damage: 100 cells $\times 4$ ). DI is based on migration length and on the amount of DNA in the tail, and it is considered a sensitive DNA measure [15].

\section{In vivo antitumor evaluation of the essential oil}

Determination of the effect of the essential oil on the growth of solid tumor in vivo: The in vivo antitumor effect was evaluated using sarcoma 180 ascites tumor cells following protocols previously described [16-18]. Ten-day-old sarcoma 180 ascites tumor cells $\left(2 \times 10^{6}\right.$ cells per $\left.500 \mu \mathrm{L}\right)$ were implanted subcutaneously into the left hind groin of mice. The essential oil was dissolved in 5\% DMSO and given to mice intraperitoneally once a day for 7 consecutive days. At the beginning of the experiment, the mice were divided into four groups, as follows: Group 1: animals treated by i.p. injection of vehicle $5 \%$ DMSO $(n=12)$; Group 2: animals treated by i.p. injection of 5-FU ( $25 \mathrm{mg} / \mathrm{kg} /$ day) $(\mathrm{n}=10)$; Group 3: animals treated by i.p. injection of the essential oil ( $50 \mathrm{mg} / \mathrm{kg} /$ day) $(n=8)$; Group 4: animals treated by i.p. injection of the essential oil $(100 \mathrm{mg} / \mathrm{kg} /$ day $)(\mathrm{n}=10)$. The treatments were started one day after tumor injection. The dosages were determined based on previous articles $[18,19]$. On day 8 , the animals were sacrificed by cervical dislocation, and the tumors were excised and weighed. The drug effects were expressed as the percent inhibition of control.

Systemic toxicological evaluation: Body weight loss, organ weight alteration, and hematological analyses were determined at the end of the above experiment, as previous described $[17,18]$. Peripheral blood samples of the mice were collected from the retroorbital plexus under light ether anesthesia, and the animals were sacrificed by cervical dislocation. After sacrifice, the liver, kidney, and spleens were removed and weighed. In hematological analysis, total leukocyte counts were determined by standard manual procedures using light microscopy.

\section{Statistical analysis}

Data were presented as mean \pm SEM (or SD) or $\mathrm{IC}_{50}$ values, and their $95 \%$ confidence intervals (CI 95\%) obtained by nonlinear regression. The differences between experimental groups were compared by ANOVA (analysis of variance) followed by the Student-Newman-Keuls ( $\mathrm{p}<0.05$ ). All statistical analyses were performed using the GraphPad program (Intuitive Software for Science).

\section{Results}

Initially, chemical compositions of three essential oil samples were analyzed by GC/FID and GC/MS. Hydrodistillation of the $X$. laevigata leaf specimens yielded essential oil superior to $1 \%$ in relation to the dry weight of the plant material. The best yield was observed for sample B with $1.58 \pm 0.12 \%$. All samples of the essential oil were dominated by sesquiterpene constituents with $95.35 \%$ in sample A, $98.60 \%$ in sample B, and $91.18 \%$ in sample C. Fig. 1 presents a representative chromatogram from GC-MS analysis of the essential oil samples. As shown in $\odot$ Table 1, it was possible to identify 44 compounds: 37 in sample A, 19 in sample $\mathrm{B}$, and 28 in sample $\mathrm{C}$. The major compounds identified in the essential oil of sample A were $\gamma$-muurolene (17.99\%), $\delta$-cadinene (13.45\%), germacrene D (9.09\%), bicyclogermacrene (7.00\%), $\alpha$ copaene (5.98\%), (E)-caryophyllene (5.43\%), $\gamma$-cadinene $(4.52 \%)$, aromadendrene (3.99\%), $\gamma$-amorphene $(3.92 \%)$, and germacrene B (3.22\%), while germacrene D (60.44\%), bicyclogermacrene (11.65\%), (E)-caryophyllene (6.37\%), germacrene B (3.67\%), $\gamma$-cadinene (3.38\%), and $\alpha$-copaene (3.33\%) were the main constituents in the essential oil of sample $B$. In sample $C$, the following predominated: germacrene D (43.62\%), bicyclogermacrene (14.63\%), (E)-caryophyllene (7.98\%), germacrene B (7.31\%), $\delta$-elemene (4.50\%), and $\alpha$-copaene (3.56\%). Although some small differences were observed in the chemical composition of the essential oil samples from $X$. laevigata specimens, the presence of $\gamma$-muurolene (0.60-17.99\%), $\delta$-cadinene (1.15-13.45\%), germacrene B (3.22-7.31\%), $\alpha$-copaene (3.33-5.98\%), germacrene D 


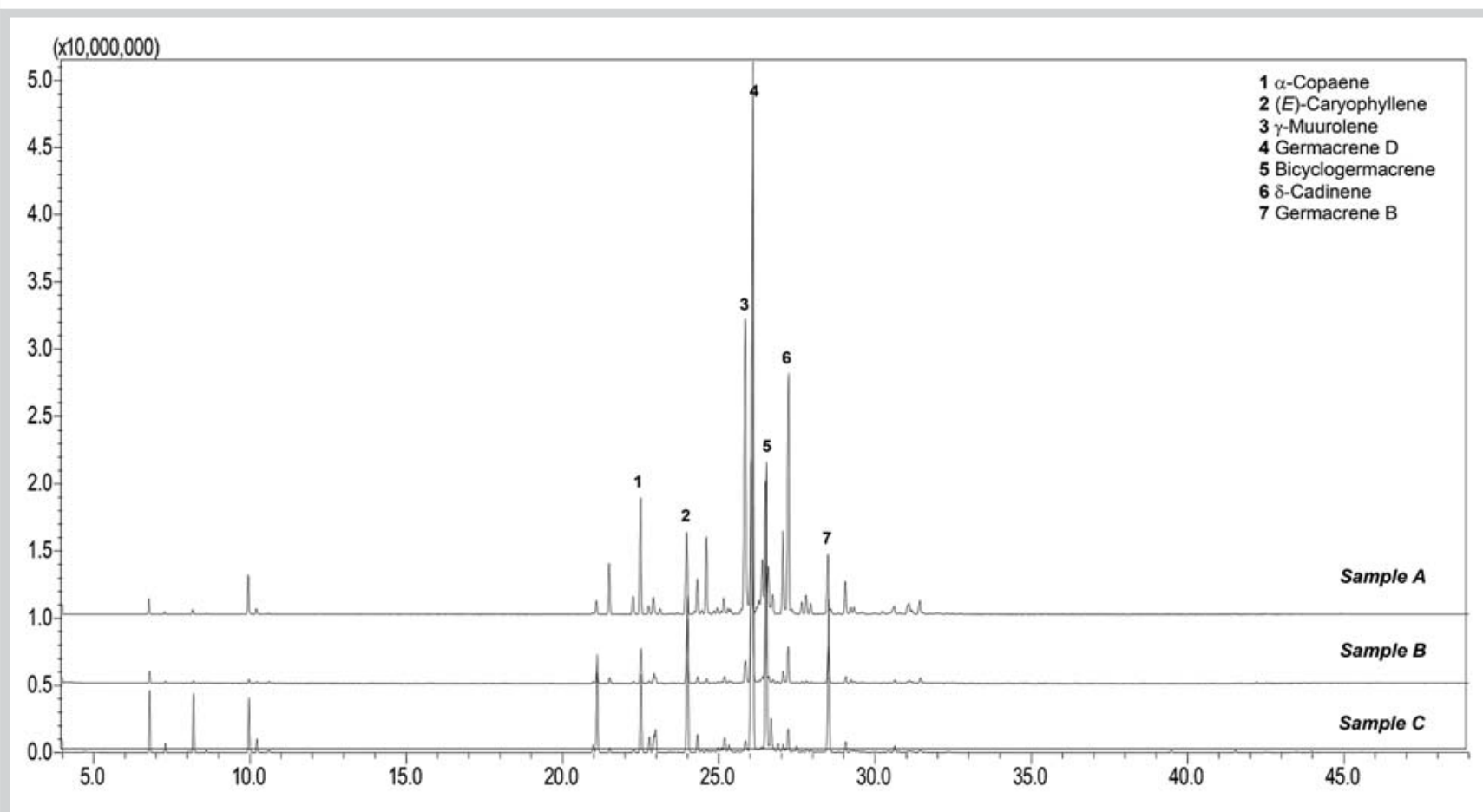

Fig. 1 Total ion current chromatogram from GC-MS analysis of the essential oil samples from leaves of Xylopia laevigata. Only the major compounds are presented in the GC-MS chromatogram. Sample A was collected at Itabaiana
Mountain National Park, sample B was collected at "Mata do Crasto" and sample $\mathrm{C}$ was collected near the campus of the Federal University of Sergipe.
(9.09-60.44\%), bicyclogermacrene (7.00-14.63\%), and (E)-caryophyllene (5.43-7.98\%) were verified as major constituents in all samples of the essential oil.

In a second set of experiments, anticancer activity of the essential oil samples was evaluated in different bioassays. The effect of the essential oil samples was assessed on normal and tumor cells in culture. Genotoxic activity on human lymphocytes and lytic activity on mouse erythrocytes were also determined. In addition, in vivo antitumor activity was assessed in Sarcoma 180-bearing mice.

The cytotoxicity of all essential oil samples was evaluated for tumor cell lines from different histotypes using the MTT assay. Doxorubicin was used as a positive control. The cytotoxicity of the essential oil was similar for all samples. Table 2 summarizes the $\mathrm{IC}_{50}$ data for cytotoxic activity. $\mathrm{IC}_{50}$ values ranging from 14.4 to $31.6 \mu \mathrm{g} / \mathrm{mL}$ were obtained in SF-295 and OVCAR-8 cell lines for sample A, from 17.9 to $27.1 \mu \mathrm{g} / \mathrm{mL}$ in SF-295 and OVCAR-8 cell lines for sample B, and from 18.5 to $27.6 \mu \mathrm{g} / \mathrm{mL}$ in OVCAR-8 and HCT-116 cell lines for sample C, respectively. Doxorubicin, used as a positive control, showed $\mathrm{IC}_{50}$ values ranging from 0.02 to $1.36 \mu \mathrm{g} / \mathrm{mL}$ in HL-60 and OVCAR-8 cell lines, respectively.

The cytotoxicity of the essential oil was also evaluated with normal cells (PBMC). The results, presented in $\bigcirc$ Table 2, show that these essential oil samples were also cytotoxic to normal cells.

Since the inhibition of tumor cell lines can be related to membrane disruption, all essential oil samples were also tested for the ability to induce lysis of mouse erythrocytes; however, they were not hemolytic, even at the highest concentration tested (500 $\mu \mathrm{g} / \mathrm{mL}$, data not shown). Triton X-100, used as a positive control, showed potent hemolytic effects.

The genotoxicity of a representative sample of the essential oil (sample A) was evaluated in human lymphocytes in culture by the alkaline comet assay at concentrations of 50,100 , and $200 \mu \mathrm{g} / \mathrm{mL}$. Genotoxicity assay was performed with only one sample since the in vitro cytotoxic effects were similar among the samples. The essential oil did not show genotoxic activity at any experimental concentration tested (data not shown). Doxorubicin, used as a positive control, showed potent genotoxic activity.

To investigate whether the essential oil has in vivo antitumor activity, mice were subcutaneously transplanted with sarcoma 180 cells and treated by the intraperitoneal route once a day for 7 consecutive days with the essential oil. Since the in vitro cytotoxic effects were similar among the samples, we decided to perform the in vivo antitumor study with only one sample. Sample B was used due to the amount of samples available. The effects of the essential oil on mice transplanted with sarcoma 180 tumor are presented in Table 3. On day 8, the average tumor weight of the control mice was $1.97 \pm 0.17 \mathrm{~g}$. In the presence of the essential oil (50 and $100 \mathrm{mg} / \mathrm{kg} /$ day), the average tumor weights were $1.24 \pm 0.09$ and $1.13 \pm 0.27 \mathrm{~g}$, respectively. Tumor growth inhibition rates were $37.3-42.5 \%$. The inhibition was significant at both doses in relation to the control group $(\mathrm{p}<0.05)$. With the $25 \mathrm{mg} / \mathrm{kg} /$ day dose, 5 -FU reduced tumor weight by $67.8 \%$ within the same period.

Systemic toxicological parameters were also examined in essential oil-treated mice. For these, body weight loss, organ weight alteration, and leukogram were determined. No statistically significant changes in the essential oil-treated mice were seen in any toxicological parameters analyzed ( $p>0.05$, data not shown). In contrast, 5-FU, used as a positive control, reduced the body weights and spleen organ weights and induced a decrease in total leukocytes ( $\mathrm{p}<0.05$, data not shown). 
Table 1 Chemical constituents of the essential oil from leaves of Xylopia laevigata.

\begin{tabular}{|c|c|c|c|c|c|c|}
\hline \multicolumn{2}{|c|}{ Compounds } & \multirow{3}{*}{$\begin{array}{l}\mathbf{R l}^{\mathbf{a}} \\
\quad 931\end{array}$} & \multirow{3}{*}{$\begin{array}{l}\mathbf{R I}^{\mathbf{b}} \\
932\end{array}$} & \multicolumn{3}{|l|}{ Leaf oil \% } \\
\hline & & & & \multirow{2}{*}{$\begin{array}{l}\text { Sample A } \\
0.48 \pm 0.14\end{array}$} & \multirow{2}{*}{$\begin{array}{l}\text { Sample B } \\
0.81 \pm 0.01\end{array}$} & \multirow{2}{*}{$\begin{array}{l}\text { Sample C } \\
2.08 \pm 0.06\end{array}$} \\
\hline 1 & $\alpha$-Pinene & & & & & \\
\hline 2 & Camphene & 946 & 946 & - & - & $0.34 \pm 0.01$ \\
\hline 3 & $\beta$-Pinene & 974 & 974 & $0.15 \pm 0.05$ & - & $2.16 \pm 0.10$ \\
\hline 4 & Limonene & 1027 & 1024 & $1.41 \pm 0.35$ & $0.34 \pm 0.01$ & $2.19 \pm 0.14$ \\
\hline 5 & (Z)- $\beta$-Ocimene & 1034 & 1032 & $0.11 \pm 0.16$ & - & $0.51 \pm 0.01$ \\
\hline 6 & $\delta$-Elemene & 1333 & 1335 & $0.72 \pm 0.01$ & $1.64 \pm 0.10$ & $4.50 \pm 0.10$ \\
\hline 7 & $\alpha$-Cubebene & 1345 & 1345 & $2.54 \pm 0.00$ & $0.48 \pm 0.04$ & $0.21 \pm 0.01$ \\
\hline 8 & $\alpha$-Ylangene & 1367 & 1373 & $1.00 \pm 0.01$ & - & - \\
\hline 9 & $\alpha$-Copaene & 1374 & 1374 & $5.98 \pm 0.08$ & $3.33 \pm 0.06$ & $3.56 \pm 0.04$ \\
\hline 10 & $\beta$-Bourbonene & 1381 & 1387 & $0.42 \pm 0.00$ & - & $0.72 \pm 0.00$ \\
\hline 11 & $\beta$-Cubebene & 1386 & 1387 & $0.95 \pm 0.06$ & $0.98 \pm 0.04$ & $0.79 \pm 0.10$ \\
\hline 12 & $\beta$-Elemene & 1387 & 1389 & - & $0.48 \pm 0.01$ & $1.06 \pm 0.07$ \\
\hline 13 & (E)-Caryophyllene & 1417 & 1417 & $5.43 \pm 0.01$ & $6.37 \pm 0.15$ & $7.98 \pm 0.00$ \\
\hline 14 & $\gamma$-Elemene & 1427 & 1430 & - & - & $0.88 \pm 0.01$ \\
\hline 15 & $\beta$-Copaene & 1427 & 1430 & $1.82 \pm 0.01$ & $0.61 \pm 0.03$ & - \\
\hline 16 & Aromadendrene & 1436 & 1439 & $3.99 \pm 0.02$ & $0.43 \pm 0.04$ & - \\
\hline 17 & trans-Muurola-3,5-diene & 1447 & 1451 & $0.31 \pm 0.04$ & - & - \\
\hline 18 & $\alpha$-Humulene & 1453 & 1452 & $0.97 \pm 0.11$ & $0.61 \pm 0.01$ & $0.67 \pm 0.02$ \\
\hline 19 & Allo-Aromadendrene & 1458 & 1458 & $0.33 \pm 0.04$ & - & $0.25 \pm 0.01$ \\
\hline 20 & cis-Cadina-1(6),4-diene & 1460 & 1461 & $0.23 \pm 0.00$ & - & - \\
\hline 21 & trans-Cadina-1(6),4-diene & 1469 & 1475 & $0.30 \pm 0.02$ & - & - \\
\hline 22 & $\gamma$-Muurolene & 1474 & 1478 & $17.99 \pm 0.25$ & $2.41 \pm 0.22$ & $0.60 \pm 0.01$ \\
\hline 23 & Germacrene D & 1480 & 1484 & $9.09 \pm 0.64$ & $60.44 \pm 0.71$ & $43.62 \pm 0.49$ \\
\hline 24 & $\delta$-Selinene & 1485 & 1492 & $0.42 \pm 0.04$ & - & - \\
\hline 25 & $y$-Amorphene & 1490 & 1495 & $3.92 \pm 0.05$ & - & - \\
\hline 26 & Bicyclogermacrene & 1494 & 1500 & $7.00 \pm 0.23$ & $11.65 \pm 0.49$ & $14.63 \pm 0.19$ \\
\hline 27 & $\alpha$-Muurolene & 1496 & 1500 & $2.50 \pm 0.03$ & $0.33 \pm 0.03$ & - \\
\hline 28 & (Z)- $\alpha$-Bisabolene & 1498 & 1506 & - & - & $1.68 \pm 0.01$ \\
\hline 29 & $\delta$-Amorphene & 1503 & 1511 & $1.38 \pm 0.02$ & - & - \\
\hline 30 & $\beta$-Bisabolene & 1505 & 1505 & - & - & $0.42 \pm 0.01$ \\
\hline 31 & $\gamma$-Cadinene & 1511 & 1513 & $4.52 \pm 0.04$ & $1.16 \pm 0.12$ & $0.37 \pm 0.01$ \\
\hline 32 & $\delta$-Cadinene & 1516 & 1522 & $13.45 \pm 0.42$ & $3.38 \pm 0.34$ & $1.15 \pm 0.01$ \\
\hline 33 & trans-Calamenene & 1520 & 1521 & $0.17 \pm 0.23$ & - & - \\
\hline 34 & trans-Cadina-1,4-diene & 1530 & 1533 & $0.63 \pm 0.06$ & - & - \\
\hline 35 & $\alpha$-Cadinene & 1534 & 1537 & $1.06 \pm 0.04$ & - & $0.17 \pm 0.00$ \\
\hline 36 & $\alpha$-Calacorene & 1539 & 1544 & $0.63 \pm 0.06$ & - & - \\
\hline 37 & Germacrene B & 1557 & 1559 & $3.22 \pm 0.00$ & $3.67 \pm 0.04$ & $7.31 \pm 0.18$ \\
\hline 38 & $\beta$-Calacorene & 1560 & 1564 & $0.30 \pm 0.01$ & - & - \\
\hline 39 & Spathulenol & 1575 & 1577 & $1.91 \pm 0.12$ & $0.67 \pm 0.04$ & $0.50 \pm 0.01$ \\
\hline 40 & Caryophyllene Oxide & 1580 & 1582 & $0.37 \pm 0.00$ & - & $0.16 \pm 0.00$ \\
\hline 41 & $\alpha$-Muurolol & 1642 & 1644 & $1.04 \pm 0.34$ & - & - \\
\hline 42 & $\delta$-Cadinol & 1653 & 1649 & $0.85 \pm 0.06$ & - & - \\
\hline 43 & Pimaradiene & 1915 & 1948 & - & - & $0.11 \pm 0.01$ \\
\hline 44 & Kaur-16-ene & 1977 & $1979^{c}$ & - & - & $0.11 \pm 0.00$ \\
\hline & Monoterpene identified & & & 2.14 & 1.15 & 7.28 \\
\hline & Sesquiterpene identified & & & 95.35 & 98.60 & 91.18 \\
\hline & Diterpene identified & & & - & - & 0.22 \\
\hline & Total identified & & & 97.49 & 99.75 & 98.68 \\
\hline
\end{tabular}

Data are presented as mean \pm SD of three analyses. ${ }^{a} \mathrm{RI}$ (calc.): retention indices on DB-5MS column calculated according to Van Den Dool \& Kratz [8]; ${ }^{\mathrm{R}} \mathrm{RI}$ : retention indices according to Adams [9]; Sample A: collected at Itabaiana Mountain National Park; Sample B: collected at "Mata do Crasto"; Sample C: collected near the campus of the Federal University of Sergipe

\section{Discussion}

\section{$\nabla$}

The present work investigated the phytochemical and antitumor activity of the essential oil from leaves of $X$. laevigata collected from wild plants growing at three different sites of the remaining Atlantic forest in Sergipe State (Brazilian Northeast). The chemical composition and anticancer activity of the essential oil from leaves of $X$. laevigata were studied here for the first time.
The essential oil from the leaves of X. laevigata was chemically characterized by the presence of the major constituents $\gamma$-muurolene, $\delta$-cadinene, germacrene B, $\alpha$-copaene, germacrene $\mathrm{D}$, bicyclogermacrene, and (E)-caryophyllene. Among them, germacrene $\mathrm{D}$, bicyclogermacrene, and $(E)$-caryophyllene could be considered chemotaxonomic markers of this species since they are found in a high concentration in all essential oil samples investigated. In addition, the minor constituents $\alpha$-pinene, limonene, $\alpha$ and $\beta$-cubebene, $\alpha$-humulene, and spathulenol have been re- 
Table 2 In vitro cytotoxic activity of the essential oil from leaves of Xylopia laevigata.

\begin{tabular}{|c|c|c|c|c|c|}
\hline \multirow[t]{2}{*}{ Cell lines } & \multirow[t]{2}{*}{ Histotype } & \multicolumn{4}{|l|}{$\mathrm{IC}_{50}(\mu \mathrm{g} / \mathrm{mL})$} \\
\hline & & Sample A & Sample B & Sample C & Doxorubicin \\
\hline \multirow[t]{2}{*}{ OVCAR-8 } & \multirow[t]{2}{*}{ Ovarian carcinoma } & 31.6 & 27.1 & 18.5 & 1.36 \\
\hline & & $26.6-37.6$ & $23.1-31.8$ & $15.3-23.0$ & $0.98-1.89$ \\
\hline \multirow[t]{2}{*}{ SF-295 } & \multirow[t]{2}{*}{ Glioblastoma } & 14.4 & 17.9 & 20.5 & 0.16 \\
\hline & & $10.2-20.3$ & $13.5-23.8$ & $18.8-22.5$ & $0.13-0.23$ \\
\hline \multirow[t]{2}{*}{ HCT-116 } & \multirow[t]{2}{*}{ Colon carcinoma } & 22.2 & 25.5 & 27.6 & $\mathrm{Nd}$ \\
\hline & & $11.7-42.1$ & $11.7-55.6$ & $19.3-39.6$ & \\
\hline \multirow[t]{2}{*}{ HL-60 } & \multirow[t]{2}{*}{ Promyelocytic leukemia } & 17.5 & 25.0 & 20.6 & 0.02 \\
\hline & & $11.7-22.4$ & $10.4-36.2$ & $16.3-25.9$ & $0.01-0.02$ \\
\hline \multirow[t]{2}{*}{ PBMC } & \multirow[t]{2}{*}{ Peripheral lymphoblast } & 63.7 & 35.3 & 56.9 & 0.97 \\
\hline & & $39.1-103.7$ & $21.2-59.0$ & $38.6-83.8$ & $0.52-1.80$ \\
\hline
\end{tabular}

Data are presented as $\mathrm{IC}_{50}$ values, and their $95 \%$ confidence interval obtained by nonlinear regression from two independent experiments performed in duplicate. Doxorubicin was used as a positive control. Sample A was collected at Itabaiana Mountain National Park, sample B was collected at "Mata do Crasto", and sample C was collected near the campus of the Federal University of Sergipe. $\mathrm{Nd}=$ not determined

Table 3 In vivo antitumor activity of the essential oil from leaves of Xylopia laevigata.

\begin{tabular}{|l|lll|}
\hline Drug & $\begin{array}{l}\text { Dose } \\
(\mathbf{m g} / \mathbf{k g} / \text { day) }\end{array}$ & $\begin{array}{l}\text { Tumor } \\
(\mathbf{g})\end{array}$ & $\begin{array}{l}\text { Inhibition } \\
(\%)\end{array}$ \\
\hline 5\% DMSO & - & $1.97 \pm 0.14$ & \\
\hline 5-FU & 25 & $0.63 \pm 0.16^{*}$ & 67.8 \\
\hline Essential oil & 50 & $1.24 \pm 0.09^{*}$ & 37.3 \\
\hline & 100 & $1.13 \pm 0.27^{*}$ & 42.5 \\
\hline
\end{tabular}

Mice were injected with sarcoma $180\left(2.0 \times 10^{6}\right.$ cells/animal, s.c.). Starting one day after tumor implantation, the animals were treated for seven consecutive days by intraperitoneal route. Data are presented as mean \pm SEM for 8-12 animals. Negative control was treated with the vehicle used for diluting the test substance ( $5 \% \mathrm{DMSO}$ ). 5-Fluorouracil (5-FU) was used as a positive control. A representative sample of the essential oil (sample B) was used. Sample B was collected at "Mata do Crasto".

* $\mathrm{p}<0.05$ compared with the 5\% DMSO group by ANOVA followed by Student-Newman-Keuls

ported in essential oils of several other species belonging to the genus Xylopia, some of them, such as $\alpha$-pinene, limonene, and spathulenol, have been found in high concentrations [20-22]. The presence of the major compounds along with the minor constituents identified $\alpha$-pinene, limonene, and spathulenol, indicating that this species is a typical member of the Annonaceae family. Although some of these volatile compounds are also present in essential oils of other families, their occurrence in Annonaceae in high concentrations, mainly in the case of bicyclogermacrene, $(E)$-caryophyllene, and germacrene, is very common and has an important chemotaxonomic relevance [7,20-22].

Although the essential oil samples have shown some difference in chemical composition, as the concentrations of germacrene D and $\gamma$-muurolene, they presented similar in vitro cytotoxic effect. Probably, the associations of the major and minor constituents are responsible for the cytotoxic activity of this essential oil. The differences in chemical composition can be related to soil and climate conditions, water stress, collection place, nutrition, and other abiotic factors.

All samples of the essential oil displayed cytotoxicity to all tumor cell lines tested, with $\mathrm{IC}_{50}$ values ranging from 14.4 to $31.6 \mu \mathrm{g} / \mathrm{mL}$. According to the preclinical anticancer drug-screening program used in this study, only those extracts/oils presenting $\mathrm{IC}_{50}$ values below $30 \mu \mathrm{g} / \mathrm{mL}$ in tumor cell line assays are considered promis- ing for anticancer drug development [23]. Therefore, the essential oil obtained from $X$. laevigata presented promising results. In addition, it inhibited tumor growth in mice in a dose-dependent manner. On the other hand, the essential oil was also cytotoxic to normal cells, presenting low selectivity, but it was not hemolytic or genotoxic.

The erythrocyte membrane is a dynamic structure that can dictate significant changes in its interaction with drugs [24]. The absence of lytic effects suggests that the cytotoxicity of the essential oil is not related to membrane disruption; probably a more specific cellular pathway is responsible for its action. On the other hand, genotoxic effects could be biologically relevant as an alternative strategy for killing tumor cells. The lack of a genotoxic effect suggests that the cytotoxicity of the essential oil is not related to DNA damage. Moreover, this effect needs to be extensively evaluated to assess the safety of novel drugs.

For the Xylopia genus, as cited above, some studies have reported that plants belonging to this genus present cytotoxic activity. The ethanolic extract of $X$. aethiopica fruits was able to induce DNA damage, cell cycle arrest in the $G_{1}$ phase, and apoptotic cell death. These effects seem to be related to the diterpene ent-15-oxokaur16-en-19-oic acid [1]. The methanol extract of $X$. aethiopica seeds was cytotoxic to some tumor cell lines [25]. Interestingly, the essential oil of $X$. aethiopica fruits also showed cytotoxic activity to epidermoid carcinoma cells (Hep-2) [26]. Extracts of the bark, wood, and stem of $X$. aromatica $[2,27]$ as well as numerous acetogenins isolated from this species $[28,29]$ showed cytotoxicity to several tumor cell lines. In X. langsdorffiana, the isolated compound xylodiol was able to inhibit cell proliferation probably by involvement of the induction of cell differentiation and apoptosis induction [3,30]. Pita et al. [31] showed that trachylobane-360, a diterpene isolated from $X$. langsdorffiana, displays antitumor effects in vitro and in vivo, without substantial systemic toxicity. In addition, the diterpenoid kaurenoic acid, isolated from $X$. sericea, showed cytotoxic, genotoxic, and mutagenic effects in many experimental protocols because it induced DNA double-strand breaks and/or inhibition of topoisomerase I [4]. In this present work, the essential oil from leaves of $X$. laevigata showed significant in vitro and in vivo anticancer potential.

Some constituents of the essential oil from leaves of $X$. laevigata have been studied for their cytotoxic activity. (E)-caryophyllene and $\alpha$-pinene were previously tested by our group and showed $\mathrm{IC}_{50}$ values $>25 \mu \mathrm{g} / \mathrm{mL}$ [32]. In another study, $(E)$-caryophyllene 
showed cytotoxic activity with an $\mathrm{IC}_{50}$ value of $\sim 20 \mu \mathrm{g} / \mathrm{mL}$ to renal cell adenocarcinoma (ACHN) and amelanotic melanoma (C32) [33]. Amiel et al. [34] reported that (E)-caryophyllene has cytotoxic activity to tumor cell lines but not to normal cells. Moreover, $(E)$-caryophyllene caused a potent induction of apoptosis, accompanied by DNA ladder and caspase- 3 catalytic activity in tumor cell lines [34]. $\alpha$-Humulene showed cytotoxic activity with an $\mathrm{IC}_{50}$ value of $11.2 \mu \mathrm{g} / \mathrm{mL}$ to hormone-dependent prostate carcinoma cells (LNCaP) [35]. Areche et al. [36] showed that spathulenol was cytotoxic to gastric adenocarcinoma cells (AGS). Limonene inhibits the growth of human gastric cancer cells through a mechanism of inducing their apoptosis [37]. In addition, limonene showed anti-metastatic and anti-angiogenic effects in animal models [38]. Others constituents such as $\gamma$-muurolene, $\delta$-cadinene, and $\alpha$-copaene have not been previously tested against tumor cell lines.

The systemic toxicological aspects were also subjected to investigation in the present study. Essential oil-treated animals did not show any significant change in body weight, macroscopy of the organs (kidney, liver, and spleen), or blood leukocyte counts. Unlike the essential oil, 5-FU, used as a positive control, reduced the body weights and spleen organ weights and induced severe leukopenia, which represents an important immunosuppression side effect [39].

In conclusion, the essential oil from leaves of $X$. laevigata is chemically characterized by the presence of $\gamma$-muurolene, $\delta$-cadinene, germacrene B, $\alpha$-copaene, germacrene $\mathrm{D}$, bicyclogermacrene, and (E)-caryophyllene as major constituents and possesses significant in vitro and in vivo anticancer potential. Therefore, further investigations to identify the molecule(s) responsible for its activity as well as elucidate the mechanism(s) of the antitumor effect exhibited are necessary.

\section{Acknowledgements}

This work was financially supported by Capes (Coordenação de Aperfeiçoamento de Pessoal de Nível Superior), CNPq (Conselho Nacional de Desenvolvimento Cientifico e Tecnológico), and FAPITEC/SE (Fundação de Amparo à Pesquisa e à Inovação Tecnológica do Estado de Sergipe). The authors thank Richard Berger for editing the English manuscript.

\section{Conflict of Interest}

$\nabla$

There is no conflict of interest among the authors.

\section{Affiliations}

${ }^{1}$ Department of Physiology, Federal University of Sergipe, São Cristóvão, Sergipe, Brazil

2 Department of Physiology and Pharmacology, Federal University of Ceará, School of Medicine, Fortaleza, Ceará, Brazil

3 Department of Chemistry, Federal University of Sergipe, São Cristóvão, Sergipe, Brazil

${ }^{4}$ Department of Biology, Federal University of Sergipe, São Cristóvão, Sergipe, Brazil

\section{References}

1 Choumessi AT, Danel M, Chassaing S, Truchet I, Penlap VB, Pieme AC, Asonganyi T, Ducommun B, Valette A. Characterization of the antiproliferative activity of Xylopia aethiopica. Cell Div 2012; 7: 1-8

2 Taylor P, Arsenak M, Abad MJ, Fernández A, Milano B, Gonto R, Ruiz MC, Fraile S, Taylor S, Estrada O, Michelangeli F. Screening of Venezuelan medicinal plant extracts for cytostatic and cytotoxic activity against tu- mor cell lines. Phytother Res advance online publication 2012; DOI: 10.1002/ptr.4752

3 Castello-Branco MV, Anazetti MC, Silva MS, Tavares JF, Diniz MF, Frungillo L, Haun M, Melo PS. Diterpenes from Xylopia langsdorffiana inhibit cell growth and induce differentiation in human leukemia cells. Z Naturforsch C 2009; 64: 650-656

4 Cavalcanti BC, Ferreira JR, Moura DJ, Rosa RM, Furtado GV, Burbano RR, Silveira ER, Lima MA, Camara CA, Saffi J, Henriques JA, Rao VS, Costa-Lotufo $L V$, Moraes MO, Pessoa C. Structure-mutagenicity relationship of kaurenoic acid from Xylopia sericeae (Annonaceae). Mutat Res 2010; 701: 153-163

5 Pontes AF, Barbosa MRV, Maas PJM. Flora Paraibana: Annonaceae Juss. Acta Bot Braz 2004; 18: 281-293

6 Silva DM, Costa EV, Nogueira PCL, Moraes VRS, Cavalcanti SCH, Salvador MJ, Ribeiro LHG, Gadelha FR, Barison A, Ferreira AG. Ent-kaurane diterpenoids and other constituents from the stem of Xylopia laevigata (Annonaceae). Quim Nova 2012; 35: 1570-1576

7 Costa EV, Dutra LM, De Jesus HCR, Nogueira PCL, Moraes VRS, Salvador MJ, Cavalcanti SCH, Dos Santos RLC, Prata APN. Chemical composition and antioxidant, antimicrobial, and larvicidal activities of the essential oils of Annona salzmannii and A. pickelii (Annonaceae). Nat Prod Commun 2011; 6: 907-912

8 Van Den Dool H, Kratz PD. A generalization of the retention index system including linear temperature programmed gas-liquid partition chromatography. J Chromatogr 1963; 11: 463-471

9 Adams RP. Identification of essential oil components by gas chromatography/mass spectrometry. Illinois: Allured Publishing Corporation; 2007

10 Mossman T. Rapid colorimetric assay for cellular growth and survival: application to proliferation and cytotoxicity assays. J Immunol Methods 1983; 65: 55-63

11 Ahmed SA, Gogal RM, Walsh JE. A new rapid and simple non-radioactive assay to monitor and determine the proliferation of lymphocytes an alternative to $[3 \mathrm{H}]$ thymidine incorporation assay. J Immunol Methods 1994; 170: 211-224

12 Jimenez PC, Fortier SC, Lotufo TMC, Pessoa C, Moraes MEA, Moraes MO, Costa-Lotufo $\mathrm{LV}$. Biological activity in extracts of ascidians (Tunicata, Ascidiacea) from the northeastern Brazilian coast. J Exp Mar Biol Ecol 2003; 287: 93-101

13 Singh NP, Mccoy MT, Tice RR, Schneider ELA. Single technique for quantitation of low levels of DNA damage in individual cells. Exp Cell Res 1988; 175: 184-191

14 Hartmann A, Speit G. The contribution of cytotoxicity to DNA effects in the single cell gel test (comet assay). Toxicol Lett 1997; 90: 183-188

15 Speit G, Hartmann A. The comet assay (single-cell gel test). A sensitive genotoxicity test for the detection of DNA damage and repair. Methods Mol Biol 1999; 113: 203-212

16 Bezerra DP, Castro FO, Alves APNN, Pessoa C, Moraes MO, Silveira ER, Lima MAS, Elmiro FJM, Costa-Lotufo LV. In vivo growth-inhibition of sarcoma 180 by piplartine and piperine, two alkaloid amides from Piper. Braz J Med Biol Res 2006; 39: 801-807

17 Bezerra DP, Castro FO, Alves APNN, Pessoa C, Moraes MO, Silveira ER, Lima MAS, Elmiro FJM, Alencar NMN, Mesquita RO, Lima MW, Lotufo LVC. In vitro and in vivo antitumor effect of 5 -FU combined with piplartine and piperine. J Appl Toxicol 2008; 28: 156-163

18 Britto ACS, Oliveira ACA, Henriques RM, Cardoso GMB, Bomfim DS, Carvalho AA, Moraes MO, Pessoa C, Pinheiro MLB, Costa EV, Bezerra DP. In vitro and in vivo antitumor effects of the essential oil from the leaves of Guatteria friesiana. Planta Med 2012; 78: 409-414

19 Bezerra DP, Marinho Filho JD, Alves AP, Pessoa C, de Moraes MO, Pessoa OD, Torres MC, Silveira ER, Viana FA, Costa-Lotufo LV. Antitumor activity of the essential oil from the leaves of Croton regelianus and its component ascaridole. Chem Biodivers 2009; 6: 1224-1231

20 Lago JHG, De Ávila Jr. P, Moreno PRH, Limberger RP, Apel MA, Henriques AT. Analysis, comparison and variation on the chemical composition from the leaf volatile oil of Xylopia aromatica (Annonaceae). Biochem Syst Ecol 2003; 31: 669-672

21 Maia JGS, Andrade EHA, Da Silva ACM, Oliveira J, Carreira LMM, Araújo $J S$. Leaf volatile oils from four Brazilian Xylopia species. Flavour Fragr J 2005; 20: 474-477

22 Tavares JF, Silva MVB, Queiroga KF, Martins RM, Silva TMS, Camara CA, Agra MF, Barbosa-Filho JM, Da Silva MS. Composition and molluscicidal properties of essential oils from leaves of Xylopia langsdorffiana A. St. Hil. Et Tul. (Annonaceae). J Essent Oil Res 2007; 19: 282-284 
23 Suffness M, Pezzuto JM. Assays related to cancer drug discovery. In: Hostettmann K, editor. Methods in plant biochemistry: assays for bioactivity. London: Academic Press; 1990: 71-133

24 Aki H, Yamamoto M. Drug binding to human erythrocytes in the process of ionic drug-induced hemolysis. Flow microcalorimetric approaches. Biochem Pharmacol 1991; 41: 133-138

25 Kuete V, Krusche B, Youns M, Voukeng I, Fankam AG, Tankeo S, Lacmata S, Efferth T. Cytotoxicity of some Cameroonian spices and selected medicinal plant extracts. J Ethnopharmacol 2011; 134: 803-812

26 Asekun OT, Adeniyi BA. Antimicrobial and cytotoxic activities of the fruit essential oil of Xylopia aethiopica from Nigeria. Fitoterapia 2004; 75: $368-370$

27 Suffredini IB, Paciencia ML, Varella AD, Younes RN. In vitro cytotoxic activity of Brazilian plant extracts against human lung, colon and CNS solid cancers and leukemia. Fitoterapia 2007; 78: 223-226

28 Colman-Saizarbitoria T, Gu ZM, Zhao GX, Zeng L, Kozlowski JF, McLaughlin JL. Venezenin: a new bioactive Annonaceous acetogenin from the bark of Xylopia aromatica. J Nat Prod 1995; 58: 532-539

29 Colman-Saizarbitoria T, Zambrano J, Ferrigni NR, Gu ZM, Ng JH, Smith $D L$, McLaughlin JL. Bioactive annonaceous acetogenins from the bark of Xylopia aromatica. J Nat Prod 1994; 57: 486-493

30 Castello-Branco MVS, Tavares JF, Silva MS, Filho JMB, Anazetti MC, Frungillo L, Haun M, Diniz MFFM, Melo PS. Xylodiol from Xylopia langsdorfiana induces apoptosis in HL60 cells. Braz J Pharmacogn 2011; 21: 1035-1042

31 Pita JC, Xavier AL, de Sousa TK, Mangueira VM, Tavares JF, de Oliveira Júnior RJ, Veras RC, Pessoa Hde L, da Silva MS, Morelli S, Ávila Vde M, da Silva TG, Diniz Mde F, Castello-Branco MV. In vitro and in vivo antitumor effect of trachylobane-360, a diterpene from Xylopia langsdorffiana. Molecules 2012; 17: 9573-9589
32 Ribeiro SS, Jesus AM, Anjos CS, Silva TB, Santos ADC, Jesus JR, Andrade MS, Sampaio TS, Gomes WF, Alves PB, Carvalho AA, Pessoa C, Moraes MO, Pinheiro MLB, Prata APN, Blank AF, Silva-Mann R, Moraes VRS, Costa EV, Nogueira PCL, Bezerra DP. Evaluation of the cytotoxic activity of some Brazilian medicinal plants. Planta Med 2012; 78: 1601-1606

33 Tundis R, Loizzo MR, Bonesi M, Menichini F, Dodaro D, Passalacqua NG, Statti G, Menichini F. In vitro cytotoxic effects of Senecio stabianus Lacaita (Asteraceae) on human cancer cell lines. Nat Prod Res 2009; 23: 1707-1718

34 Amiel E, Ofir R, Dudai N, Soloway E, Rabinsky T, Rachmilevitch S. $\beta$-Caryophyllene, a compound isolated from the biblical balm of gilead (Commiphora gileadensis), is a selective apoptosis inducer for tumor cell lines. Evid Based Complement Alternat Med 2012; 2012: 872394

35 Loizzo MR, Tundis R, Statti GA, Menichini F. Jacaranone: A cytotoxic constituent from Senecio ambiguus subsp. ambiguus (Biv.) DC. against renal adenocarcinoma ACHN and prostate carcinoma LNCaP cells. Arch Pharm Res 2007; 30: 701-707

36 Areche C, Schmeda-Hirschmann G, Theoduloz C, Rodríguez JA. Gastroprotective effect and cytotoxicity of abietane diterpenes from the Chilean Lamiaceae Sphacele chamaedryoides (Balbis) Briq. J Pharm Pharmacol 2009; 61: 1689-1697

37 Lu XG, Feng BA, Zhan LB, Yu ZH. D-limonene induces apoptosis of gastric cancer cells. Zhonghua Zhong Liu Za Zhi 2003; 25: 325-327

38 Lu XG, Zhan LB, Feng BA, Qu MY, Yu LH, Xie JH. Inhibition of growth and metastasis of human gastric cancer implanted in nude mice by d-limonene. World J Gastroenterol 2004; 10: 2140-2144

39 Takiguchi N, Saito N, Nunomura M, Kouda K, Oda K, Furuyama N, Nakajima $\mathrm{N}$. Use of 5-FU plus hyperbaric oxygen for treating malignant tumors: evaluation of antitumor effect and measurement of 5-FU in individual organs. Cancer Chemother Pharmacol 2001; 47: 11-14 